\title{
Syntheses and Molecular Structures of Copper(II) Complexes with 1,3,5-Tris(pyrazol-1-ylmethyl)benzene $\dagger$
}

\author{
Wen-Kuen Chang, Shiann-Cherng Sheu, Gene-Hsiang Lee, Yu Wang, * Tong-Ing Ho * and \\ Yuan-Chuan Lin \\ Department of Chemistry, National Taiwan University, Taipei, Taiwan, Republic of China
}

\begin{abstract}
A new trifunctional ligand, 1,3,5-tris(pyrazol-1-ylmethyl)benzene $(L)$, has been prepared. It reacts with 1 equivalent of copper(II) perchlorate to form the complex $\left[\mathrm{CuL}_{2}\left(\mathrm{ClO}_{4}\right)_{2}\left(\mathrm{H}_{2} \mathrm{O}\right)_{2}\right] 1$ and with 1.5 equivalents of copper(II) chloride to form $\left[\left\{\mathrm{Cu}_{3} \mathrm{~L}_{2} \mathrm{Cl}_{6}\left(\mathrm{H}_{2} \mathrm{O}\right)_{2}\right\}_{n}\right] 3$. The macromolecular complex $\left[\left\{\mathrm{Cu}_{2} \mathrm{~L}_{2} \mathrm{Cl}_{2}\left(\mathrm{ClO}_{4}\right)_{2}\left(\mathrm{H}_{2} \mathrm{O}\right)_{4}\right\}_{n}\right] 2$ was formed by the reaction of 1 with 1 equivalent of $\mathrm{CuCl}_{2}$. Complex 3 can also be prepared from 2 with 1 equivalent of $\mathrm{CuCl}_{2}$ or from 1 with 2 equivalents of $\mathrm{CuCl}_{2}$. The mixed-metal complex $\left[\left\{\mathrm{Cu}_{2} \mathrm{CoL}_{2} \mathrm{Cl}_{8}\left(\mathrm{H}_{2} \mathrm{O}\right)_{3}\right\}_{n}\right] 4$ was prepared from 2 with cobalt(ii) chloride. The molecular structures of complexes 1, 2 and 4 have been characterized by $X$-ray diffraction: 1, monoclinic, space group $P 2_{1}$, $a=10.255(1), b=20.218(3), c=10.316(2) \AA, \beta=106.21(1)^{\circ}, Z=2 ; 2$, monoclinic, space group $P 2, c$. $a=11.288(2), b=13.633(3), c=15.173(3) \AA, \beta=104.635(15)^{\circ}, Z=2 ; 4$, monoclinic, space group $C 2 / c, a=7.473(3), b=22.137(7), c=28.155(10) \AA, \beta=96.21(3)^{\circ}, Z=4$. The co-ordination sphere of copper(II) in 1 and 2 is distorted square pyramidal and 2-4 have polymeric structures.
\end{abstract}

The chemistry of polynuclear complexes containing copper or copper mixed with other metal ions has been the subject of much interest in chelate systems. ${ }^{1-16}$ Some dicopper complexes were prepared as models for copper proteins in the hope that they would mimic the active site of biological systems. ${ }^{17-19}$

For example, the ligand 2,6-bis(acetylacetoxymethyl)pyridine reacts with $\mathrm{Cu}^{\mathrm{II}}$ and $\mathrm{Pd}^{\mathrm{II}}$ to form $\mathrm{Cu}^{\mathrm{II}} \mathrm{Pd}^{\mathrm{II}} \mathrm{Cu}^{\mathrm{II}}$ trinuclear complexes, ${ }^{11}$ ethylenediamine Schiff-base derivatives of $o$ acetoacetylphenol react with $\mathrm{Cu}^{\mathrm{II}}$ and $\mathrm{Ni}^{\mathrm{II}}$ to form $\mathrm{Cu}^{\mathrm{II}} \mathrm{Ni}^{\mathrm{II}}$ binuclear complexes ${ }^{12-14}$ and some of the copper-metal complexes were synthesised by use of macrocyclic ligands. ${ }^{15,16}$ The mixed copper-metal complexes were studied as representations of the metal-containing sites in metallobiomolecules $^{16,20-22}$ and for their relevance to versatile catalytic systems in synthetic processes. ${ }^{11,23-26}$

In an effort to develop new polynuclear complexes, we were interested in studying the metal complexation of polyfunctional pyrazole ligands. We prepared previously the 4-methyl-2,6bis(pyrazol-1-ylmethyl)phenol ligand, which reacted with $\mathrm{Zn}^{\text {II }}$ to give a binuclear complex. ${ }^{27}$ In this paper we report the synthesis and structure of mono-, bi- and tri-nuclear complexes of 1,3,5-tris(pyrazol-1-ylmethyl)benzene with $\mathrm{Cu}^{\mathrm{II}}$ and $\mathrm{Co}^{\mathrm{II}}$.

\section{Experimental}

Chemicals. - All reagents and solvents were purchased from commercial sources and used as received unless noted otherwise. 1,3,5-Tris(bromomethyl)benzene was prepared according to the literature. ${ }^{28}$

Physical Methods.-Melting points were obtained with a Thomas Hoover capillary apparatus in open capillaries and are uncorrected. Proton NMR spectra were recorded on a Bruker AM-200WB instrument at $200 \mathrm{MHz}$ using $\mathrm{CDCl}_{3}$ as solvent and ESR spectra on a Bruker ESP $300 \mathrm{X}$-band instrument using diphenylpicrylhydrazyl (dpph) as standard. Magnetic susceptibilities were measured using the Faraday method on a CAHN 2000 instrument with $\mathrm{Hg}\left[\mathrm{Co}(\mathrm{SCN})_{4}\right]$ as standard and

† Supplementary data available: see Instructions for Authors, J. Chem. Soc., Dalton Trans., 1993, Issue 1, pp. xxiii-xxviii. diamagnetic corrections were made using Pascal's constants. Mass spectra were recorded on a Finnigan MAT TSQ-46C instrument, infrared spectra on a Perkin Elmer 983G spectrometer using $\mathrm{KBr}$ as support, and ultraviolet-visible spectra on a Hewlett-Packard $8452 \mathrm{~A}$ diode-array spectrometer using $\mathrm{MeOH}$ as solvent. Elemental analyses were obtained using a Hitachi CHN-O-Rapid Analyser instrument.

Syntheses.-1,3,5-Tris(pyrazol-1-ylmethyl)benzene (L). Pyrazole $(2.04 \mathrm{~g}, 30 \mathrm{mmol})$ and sodium carbonate $(3.18 \mathrm{~g}, 30 \mathrm{mmol})$ were dissolved in benzene $\left(20 \mathrm{~cm}^{3}\right)$ then $1,3,5$-tris(bromomethyl)benzene $(3.57 \mathrm{~g}, 10 \mathrm{mmol})$ in benzene $\left(20 \mathrm{~cm}^{3}\right)$ was added. After refluxing for $3 \mathrm{~h}$ the solvents were removed under reduced pressure and the residue was washed by acetone. The product was purified by column chromatography (silica gel 60) using ethyl acetate-hexane $(1: 1)\left(R_{\mathrm{f}}=0.33\right)$ as eluent. After solvent evaporation the crude product was crystallized from a mixture of ethyl acetate and hexane to obtain a white solid (yield $1.3 \mathrm{~g}, 40 \%$ ), m.p. $60-61^{\circ} \mathrm{C}$ (Found: C, 67.50; H, 5.70; $\mathrm{N}, 26.30$. Calc. for $\mathrm{C}_{18} \mathrm{H}_{18} \mathrm{~N}_{6}: \mathrm{C}, 67.90 ; \mathrm{H}, 5.65 ; \mathrm{N}, 26.40 \%$ ). Mass spectrum: $m / z 318,250,182$ and $114 .{ }^{1} \mathrm{H}$ NMR $\left(\mathrm{CDCl}_{3}\right)$ : $\delta 5.22\left(6 \mathrm{H}, \mathrm{s}\right.$, aryl $\left.\mathrm{CH}_{2} \mathrm{~N}\right), 6.24\left(3 \mathrm{H}, \mathrm{t}, J 2.0\right.$, pyrazolyl $\left.\mathrm{C}^{4} \mathrm{H}\right)$, $6.89(3 \mathrm{H}, \mathrm{s}$, aryl $\mathrm{H}), 7.32\left(3 \mathrm{H}, \mathrm{d}, J 1.0\right.$, pyrazolyl $\left.\mathrm{C}^{5} \mathrm{H}\right)$ and 7.50 $\left(3 \mathrm{H}, \mathrm{d}, J 1.0 \mathrm{~Hz}\right.$, pyrazolyl C $\left.{ }^{3} \mathrm{H}\right)$. Infrared: $v_{\max } 3115 \mathrm{~m}, 1604 \mathrm{~m}$, $1511 \mathrm{~m}, 1431 \mathrm{~m}, 1397 \mathrm{~s}, 1055 \mathrm{~s}$ and $752 \mathrm{~s} \mathrm{~cm}^{-1}$.

$\left[\mathrm{CuL}_{2}\left(\mathrm{ClO}_{4}\right)_{2}\left(\mathrm{H}_{2} \mathrm{O}\right)_{2}\right]$ 1. Copper(II) perchlorate hexahydrate $(370 \mathrm{mg}, 1 \mathrm{mmol})$ and $\mathrm{L}(318 \mathrm{mg}, 1 \mathrm{mmol})$ were dissolved in methanol $\left(10 \mathrm{~cm}^{3}\right)$. The mixture was stirred for $5 \mathrm{~min}$ at room temperature and filtered. Blue crystals were obtained by slow diffusion of diethyl ether into the mixture (Found: $\mathrm{C}, 46.00$; $\mathrm{H}, 4.35 ; \mathrm{N}, 17.95$. Calc. for $\mathrm{C}_{36} \mathrm{H}_{40} \mathrm{Cl}_{2} \mathrm{CuN}_{12} \mathrm{O}_{10}$ : C, 46.25; $\mathrm{H}, 4.30 ; \mathrm{N}, 17.95 \%$ ). Infrared: $v_{\max } 3115 \mathrm{~m}, 1606 \mathrm{~m}, 1512 \mathrm{~m}$, $1286 \mathrm{~s}, 1089 \mathrm{~s}, 747 \mathrm{~s}$ and $625 \mathrm{sm}^{-1} . \lambda_{\max }(\mathrm{MeOH}) 223(11763)$, 269 (sh, 1952) and $318 \mathrm{~nm}\left(\mathrm{sh}, \varepsilon 488 \mathrm{dm}^{3} \mathrm{~mol}^{-1} \mathrm{~cm}^{-1}\right)$.

$\left[\left\{\mathrm{Cu}_{2} \mathrm{~L}_{2} \mathrm{Cl}_{2}\left(\mathrm{ClO}_{4}\right)_{2}\left(\mathrm{H}_{2} \mathrm{O}\right)_{4}\right\}_{n}\right]$ 2. (a) Copper(II) chloride dihydrate $(170 \mathrm{mg}, 1 \mathrm{mmol})$ and $\mathrm{L}(318 \mathrm{mg}, 1 \mathrm{mmol})$ were dissolved in methanol $\left(10 \mathrm{~cm}^{3}\right)$. This solution was treated with $\mathrm{Cu}\left(\mathrm{ClO}_{4}\right)_{2} \cdot 6 \mathrm{H}_{2} \mathrm{O}(370 \mathrm{mg}, 1 \mathrm{mmol})$, stirred for $5 \mathrm{~min}$ at room temperature and filtered. Greenish blue crystals were obtained by slow diffusion of diethyl ether into the mixture (Found: C, 38.55; $\mathrm{H}, 4.00 ; \mathrm{N}, 14.95$. Calc. for $\mathrm{C}_{36} \mathrm{H}_{44} \mathrm{Cl}_{4} \mathrm{Cu}_{2} \mathrm{~N}_{12} \mathrm{O}_{12}$ : C, 39.10; H, 4.00; N, 15.20\%). Infrared: $v_{\max } 3541(\mathrm{br}), 3481(\mathrm{br})$, 

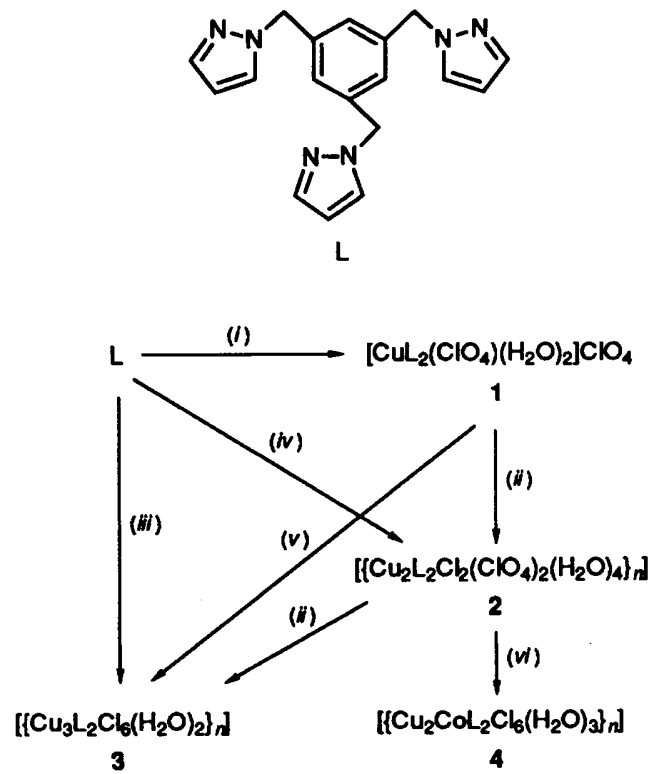

Scheme 1 (i) 1 equivalent $\mathrm{Cu}\left(\mathrm{ClO}_{4}\right)_{2} \cdot 6 \mathrm{H}_{2} \mathrm{O}, \mathrm{MeOH}$; (ii) 1 equivalent $\mathrm{CuCl}_{2} \cdot 2 \mathrm{H}_{2} \mathrm{O}$, MeOH; (iii) 1.5 equivalents $\mathrm{CuCl}_{2} \cdot 2 \mathrm{H}_{2} \mathrm{O}, \mathrm{MeOH}$; (iv) 1 equivalent $\mathrm{CuCl}_{2} \cdot 2 \mathrm{H}_{2} \mathrm{O}$ and $\mathrm{Cu}\left(\mathrm{ClO}_{4}\right)_{2} \cdot 6 \mathrm{H}_{2} \mathrm{O}, \mathrm{MeOH}$; (v) 2 equivalents $\mathrm{CuCl}_{2} \cdot 2 \mathrm{H}_{2} \mathrm{O}, \mathrm{MeOH}$; (vi) 1 equivalent $\mathrm{CoCl}_{2} \cdot 6 \mathrm{H}_{2} \mathrm{O}$, $\mathrm{MeOH}$

$3119 \mathrm{~m}, 1607 \mathrm{~m}, 1515 \mathrm{~m}, 1150 \mathrm{~s}, 1074 \mathrm{~s}, 1051 \mathrm{~s}, 770 \mathrm{~s}$ and $626 \mathrm{sm}^{-1}$. $\lambda_{\max }(\mathrm{MeOH}) 224$ (14.946), 268 (6.250) and $322 \mathrm{~nm}$, (sh, $\varepsilon 0.815$ $\left.\mathrm{dm}^{3} \mathrm{~g}^{-1} \mathrm{~cm}^{-1}\right)$.

(b) Complex $1(93.5 \mathrm{mg}, 0.1 \mathrm{mmol})$ in methanol $\left(10 \mathrm{~cm}^{3}\right)$ was added to a solution of $\mathrm{CuCl}_{2} \cdot 2 \mathrm{H}_{2} \mathrm{O}(17 \mathrm{mg}, 0.1 \mathrm{mmol})$ in methanol $\left(5 \mathrm{~cm}^{3}\right)$ and the solution was filtered. Slow diffusion of diethyl ether into the mixture gave greenish blue crystals. Infrared: $v_{\max } 3540(\mathrm{br}), 3479(\mathrm{br}), 3118 \mathrm{~m}, 1607 \mathrm{~m}, 1515 \mathrm{~m}, 1151 \mathrm{~s}$, $1074 \mathrm{~s}, 1051 \mathrm{~s}, 770 \mathrm{~s}$ and $626 \mathrm{sm}^{-1}$.

$\left[\left\{\mathrm{Cu}_{3} \mathrm{~L}_{2} \mathrm{Cl}_{6}\left(\mathrm{H}_{2} \mathrm{O}\right)_{2}\right\}_{n}\right] 3($ a) Copper(II) chloride dihydrate $(25.5 \mathrm{mg}, 0.15 \mathrm{mmol})$ and $\mathrm{L}(31.8 \mathrm{mg}, 0.1 \mathrm{mmol})$ were dissolved in methanol $\left(20 \mathrm{~cm}^{3}\right)$. The mixture was stirred for $5 \mathrm{~min}$ at room temperature and filtered. The pale green product 3 was obtained by slow diffusion of diethyl ether into the mixture (Found: C, 40.30; $\mathrm{H}, 3.80 ; \mathrm{N}, 15.60$. Calc. for $\mathrm{C}_{36} \mathrm{H}_{40} \mathrm{Cl}_{6} \mathrm{Cu}_{3} \mathrm{~N}_{12} \mathrm{O}_{2}$ : C, 40.20; H, 3.75; N, 15.60\%). Infrared: $v_{\max } 3519$ (br), $3116 \mathrm{~m}, 1608 \mathrm{~m}, 1514 \mathrm{~m}, 1412 \mathrm{~s}, 1280 \mathrm{~m}, 1073 \mathrm{~s}$ and $760 \mathrm{sm}^{-1}$. $\lambda_{\max }(\mathrm{MeOH}) 241$ (16.749), 270 (10.409) and $322 \mathrm{~nm}$ (sh, 3.346 $\left.\mathrm{dm}^{3} \mathrm{~g}^{-1} \mathrm{~cm}^{-1}\right)$.

(b) Complex $1(93.5 \mathrm{mg}, 0.1 \mathrm{mmol})$ in methanol $\left(15 \mathrm{~cm}^{3}\right)$ was added to a solution of $\mathrm{CuCl}_{2} \cdot 2 \mathrm{H}_{2} \mathrm{O}(34 \mathrm{mg}, 0.2 \mathrm{mmol})$ in methanol $\left(5 \mathrm{~cm}^{3}\right)$ and the solution was filtered. Slow diffusion of diethyl ether into the mixture gave a pale green product. Infrared: $v_{\max } 3456(\mathrm{br}), 3111 \mathrm{~m}, 1608 \mathrm{~m}, 1515 \mathrm{~m}, 1416 \mathrm{~s}, 1277 \mathrm{~m}$, $1071 \mathrm{~s}$ and $759 \mathrm{~s} \mathrm{~cm}^{-1}$.

(c) Complex $2(110 \mathrm{mg}, 0.1 \mathrm{mmol})$ in methanol $\left(15 \mathrm{~cm}^{3}\right)$ was added to a solution of $\mathrm{CuCl}_{2} \cdot 2 \mathrm{H}_{2} \mathrm{O}(17 \mathrm{mg}, 0.1 \mathrm{mmol})$ in methanol $\left(5 \mathrm{~cm}^{3}\right)$ and the solution was filtered. Slow diffusion of diethyl ether into the mixture gave a pale green product. Infrared: $v_{\max } 3424(\mathrm{br}), 3111 \mathrm{~m}, 1608 \mathrm{~m}, 1514 \mathrm{~m}, 1415 \mathrm{~s}, 1277 \mathrm{~m}$, $1071 \mathrm{~s}$ and $759 \mathrm{~s} \mathrm{~cm}^{-1}$

$\left[\left\{\mathrm{Cu}_{2} \mathrm{CoL}_{2} \mathrm{Cl}_{6}\left(\mathrm{H}_{2} \mathrm{O}\right)_{3}\right\}_{n}\right] 4$. Complex $2(110 \mathrm{mg}, 0.1 \mathrm{mmol})$ in methanol $\left(15 \mathrm{~cm}^{3}\right)$ was added to a solution of $\mathrm{CoCl}_{2} \cdot 6 \mathrm{H}_{2} \mathrm{O}$ $(23.8 \mathrm{mg}, 0.1 \mathrm{mmol})$ in methanol $\left(5 \mathrm{~cm}^{3}\right)$ and the solution was filtered. Slow diffusion of diethyl ether into the mixture gave green crystals (Found: C, 40.20; H, 3.75; N, 15.70. Calc. for $\mathrm{C}_{36} \mathrm{H}_{42} \mathrm{Cl}_{6} \mathrm{CoCu}_{2} \mathrm{~N}_{12} \mathrm{O}_{3}: \mathrm{C}, 39.70 ; \mathrm{H}, 3.90 ; \mathrm{N}, 15.45 \%$ ). Infrared: $v_{\max } 3444(\mathrm{br}), 3127 \mathrm{~m}, 1609 \mathrm{~m}, 1513 \mathrm{~m}, 1417 \mathrm{~s}, 1290 \mathrm{~m}, 1070 \mathrm{~s}$ and $759 \mathrm{~s} \mathrm{~cm}^{-1} . \lambda_{\max }(\mathrm{MeOH}) 238(15.351), 267(7.897)$ and $320 \mathrm{~nm}$ (sh, $\left.3.321 \mathrm{dm}^{3} \mathrm{~g}^{-1} \mathrm{~cm}^{-1}\right)$.

Structure Determination.-Suitable crystals of complexes 1, 2 and 4 were chosen. Intensity data were collected at room temperature on a CAD-4 diffractometer using monochromated Mo-K $\alpha$ radiation $(\lambda=0.71069 \AA)$. The unit-cell constants were derived from a least-squares refinement of 25 setting reflections. The $\theta-2 \theta$ scan technique and a variable scan speed were used to obtain the integrated intensities. Three reference reflections were monitored throughout the measurement; the variation of the intensities was less than $2 \%$ for complexes 2 and 4 , and there was a total decay of $7 \%$ for complex 1 . Absorption corrections were applied according to an experimental $\psi$ rotation curve. Other details of the crystal data are given in Table 1.

The structures were solved by the heavy-atom method. The atomic parameters were obtained from subsequent Fourier syntheses and least-squares refinement. The final results for all the non-hydrogen are given in Table 3. For all the crystals a weighting scheme of the form $1 /\left[\sigma^{2}\left(F_{\mathrm{o}}\right)+k\left(F_{\mathrm{o}}\right)^{2}\right], k=0.0001$ in complexes 1 and 2 and $k=0$ in 4 , was used. All the hydrogenatom parameters were calculated according to the ideal geometry and were not refined. The structural analyses were carried out on a MicroVaxIII computer using NRCVAX programs. ${ }^{29}$ Atomic scattering factors were taken from ref. 30 .

Additional material available from the Cambridge Crystallographic Data Centre comprises H-atom coordinates, thermal parameters and remaining bond lengths and angles.

\section{Results and Discussion}

Synthesis.-The ligand 1,3,5-tris(pyrazol-1-ylmethyl)benzene (L) was prepared as follows. First the bromination ${ }^{28}$ of 1,3,5trimethylbenzene gives 1,3,5-tris(bromomethyl)benzene, which is then treated with pyrazole and sodium carbonate in benzene to produce the ligand, an air-stable white substance. Reactions of metal(II) ions and the ligand (L), which possesses three potential nitrogen donor sites in the pyrazolyl rings, result in formation of complexes 1-4. The 1:1 reaction of the ligand and $\mathrm{Cu}\left(\mathrm{ClO}_{4}\right)_{2} \cdot 6 \mathrm{H}_{2} \mathrm{O}$ gives complex 1 in which only one $\mathrm{N}$ atom coordinates to copper(II). Complex 1 continues to react with 1 equivalent of $\mathrm{CuCl}_{2} \cdot 2 \mathrm{H}_{2} \mathrm{O}$ to form complex 2. In this case the second free $\mathrm{N}$ atom co-ordinates to copper(II), and polymerization occurs. Complex 2 also can be synthesised by the reaction of the ligand with 1 equivalent of $\mathrm{CuCl}_{2} \cdot 2 \mathrm{H}_{2} \mathrm{O}$ and 1 equivalent of $\mathrm{Cu}\left(\mathrm{ClO}_{4}\right)_{2} \cdot 6 \mathrm{H}_{2} \mathrm{O}$. It reacts with 1 equivalent of $\mathrm{CuCl}_{2} \cdot 2 \mathrm{H}_{2} \mathrm{O}$ to give complex 3 or with 1 equivalent of $\mathrm{CoCl}_{2} \cdot 6 \mathrm{H}_{2} \mathrm{O}$ to give 4 , involving coordination of the third free $\mathrm{N}$ atom of 2 and polymerization. Also complex 3 can be synthesised by the reaction of the ligand with 1.5 equivalents of $\mathrm{CuCl}_{2} \cdot 2 \mathrm{H}_{2} \mathrm{O}$ and of complex 1 with 2 equivalents of $\mathrm{CuCl}_{2} \cdot 2 \mathrm{H}_{2} \mathrm{O}$. All synthetic sequences are shown in Scheme 1 .

Molecular Structure of $\left[\mathrm{CuL}_{2}\left(\mathrm{ClO}_{4}\right)\left(\mathrm{H}_{2} \mathrm{O}\right)_{2}\right] \mathrm{ClO}_{4}$ 1.-The molecular structure is shown in Fig. 1, selected bond distances and angles in Table 2.

Complex 1 is a monocopper(II) compound. The copper(II) ion is co-ordinated by two pyrazolyl nitrogen atoms at $\mathrm{Cu}-\mathrm{N}(1 \mathrm{~A})$ $2.019(4)$ and $\mathrm{Cu}-\mathrm{N}(1 \mathrm{~B}) 1.988(4) \AA$, and two water oxygen atoms at $\mathrm{Cu}-\mathrm{O}(1) 1.924(4)$ and $\mathrm{Cu}-\mathrm{O}(2) \mathrm{1.901(4)} \AA$. Only one oxygen atom $O(3)$ of the perchlorate ligand is co-ordinated $[\mathrm{Cu}-\mathrm{O}(3) 2.411(3) \AA]$ and another perchlorate anion is not co-ordinated. The co-ordination sphere of copper(II) can be described as distorted square pyramidal ${ }^{31}$ with two oxygen atoms, $O(1)$ and $O(2)$, of the water molecules and two nitrogen atoms, $\mathrm{N}(1 \mathrm{~A})$ and $\mathrm{N}(1 \mathrm{~B})$, of the pyrazolyl rings of the ligand, in the square plane and $O(3)$ at the apical position. The $\mathrm{O}(1)-\mathrm{Cu}-\mathrm{O}(2)$ angle is $178.76(15)^{\circ}$, which is near to the theoretical value of $180^{\circ}$. The $\mathrm{N}(1 \mathrm{~A})-\mathrm{Cu}-\mathrm{O}(3)$ [92.11(15)], $\mathrm{N}(1 \mathrm{~B})-\mathrm{Cu}-\mathrm{O}(3)[97.78(14)], \mathrm{O}(1)-\mathrm{Cu}-\mathrm{O}(3)[85.69(15)]$ and $\mathrm{O}(2)-\mathrm{Cu}-\mathrm{O}(3)\left[95.03(17)^{\circ}\right]$ angles show distortion from the ideal value of $90^{\circ}$ in the perfectly square-pyramidal geometry.

Molecular Structure of $\left[\mathrm{Cu}_{2} \mathrm{~L}_{2} \mathrm{Cl}_{2}\left(\mathrm{H}_{2} \mathrm{O}\right)_{2}\right]\left[\mathrm{ClO}_{4}\right]_{2} \cdot 2 \mathrm{H}_{2} \mathrm{O}$ 2.-Selected bond distances and angles are shown in Table 2 


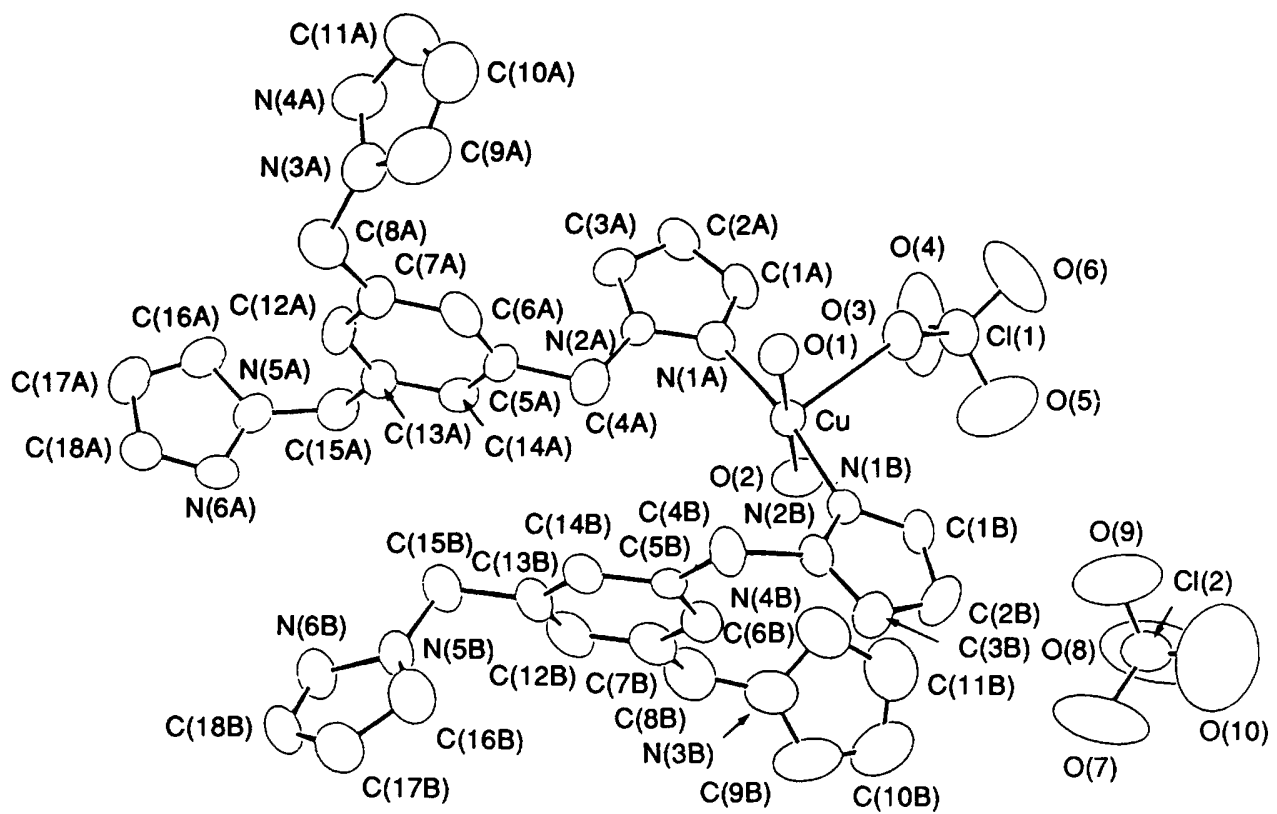

Fig. 1 The molecular structure of complex 1

Table 1 Crystallographic data for the complexes

$\begin{array}{ll}\text { Complex } & 1 \\ \text { Formula } & {\left[\mathrm{CuL}_{2}\left(\mathrm{ClO}_{4}\right)\left(\mathrm{H}_{2} \mathrm{O}\right)_{2}\right] \mathrm{ClO}_{4}} \\ M & 935.2 \\ \text { Crystal size/mm } & 0.35 \times 0.40 \times 0.50 \\ \text { Crystal symmetry } & \text { Monoclinic } \\ \text { Space group } & P 2_{1} \\ a / \AA & 10.255(1) \\ b / \AA & 20.218(3) \\ c / \AA & 10.316(2) \\ \beta /{ }^{\circ} & 106.11(1) \\ U / \AA^{3} & 2053.8(5) \\ Z & 2 \\ F(000) & 946 \\ D_{c} / \mathrm{Mg} \mathrm{m}^{-3} & 1.516 \\ \mu / \mathrm{mm}^{-1} & 0.73 \\ 2 \theta \text { range/ } & 2-50 \\ \mathrm{Scan} \text { parameters } & 1.3+0.7 \tan \theta \\ \text { Total number of reflections } & 3707(3309>2 \sigma) \\ R, R^{\prime} & 0.038,0.043 \\ S & 2.21\end{array}$

2

$\left[\mathrm{Cu}_{2} \mathrm{~L}_{2} \mathrm{Cl}_{2}\left(\mathrm{H}_{2} \mathrm{O}\right)_{2}\right]\left[\mathrm{ClO}_{4}\right]_{2} \cdot 2 \mathrm{H}_{2} \mathrm{O}$

1105.7

$0.15 \times 0.30 \times 0.50$

Monoclinic

$P 2_{1} / c$

$11.288(2)$

$13.633(3)$

15.173(3)

$104.635(15)$

2259.2(8)

2

1132

1.625

1.25

$2-45$

$1.8+0.7 \tan \theta$

$2947(2220>2 \sigma)$

$0.055,0.062$

2.98
$\left[\mathrm{Cu}_{2} \mathrm{CoL}_{2} \mathrm{Cl}_{6}\right] \cdot 3 \mathrm{H}_{2} \mathrm{O}$

1080.3

$0.15 \times 0.20 \times 0.20$

Monoclinic

C $2 / c$

7.474(3)

22.137(7)

$28.155(10)$

96.21(3)

4630(3)

4

2211

1.550

1.66

$2-45$

$1.4+0.7 \tan \theta$

$3018(1923>2 \sigma)$

$0.062,0.053$

3.81 and the repeating unit in Fig. 2. The co-ordination sphere of copper(II) in this polymeric structure is distorted square pyramidal ${ }^{31}$ with one bridging chloride ion $\mathrm{Cl}(1)$, one oxygen atom $\mathrm{O}(1)$ of the water and two nitrogen atoms, $N(1)$ and $N(3)$, of the pyrazolyl rings of the ligands in the equatorial and another bridging chloride ion $\mathrm{Cl}\left(1^{\prime}\right)$ at the apical position. Two $\mathrm{Cu}-\mathrm{N}$ distances at 2.009(5) and 2.025(6) $\AA$ and the $\mathrm{Cu}-\mathrm{N}$ distances of complexes 1 and 4 are within the ranges observed for other complexes. ${ }^{2,5,9,32-36}$

Each copper(II) ion is bridged by two ligands and two chloride ions to form a polymeric structure. In the dicopper unit, two copper(II) ions and two bridging chloride ions form a centrosymmetric planar four-membered ring. Long $\left[\mathrm{Cu}-\mathrm{Cl}\left(1^{\prime}\right)\right.$ $2.6847(19) \AA]$ and short distances [Cu-Cl(1) 2.2764(22) $\AA]$ can be distinguished in this ring and the $\mathrm{Cu}-\mathrm{Cl}-\mathrm{Cu}^{\prime}$ angle is $87.31(6)^{\circ}$ [giving a value of $92.69(7)^{\circ}$ for the $\mathrm{Cl}(1)-\mathrm{Cu}-\mathrm{Cl}\left(1^{\prime}\right)$ angle]. ${ }^{3}$ The $\mathrm{Cu} \cdot \cdots \mathrm{Cu}^{\prime}$ distance is $3.437(2) \AA$. One oxygen atom of the water molecule is co-ordinated to each copper(II) and the $\mathrm{Cu}-\mathrm{O}(1)$ distance is $1.978(5) \AA$. There are two water molecules of crystallization and two perchlorate counter anions in each dicopper unit of the complex.
Molecular Structure of $\left[\mathrm{Cu}_{2} \mathrm{CoL}_{2} \mathrm{Cl}_{6}\right] \cdot 3 \mathrm{H}_{2} \mathrm{O} 4$ - - Complex 4 is a mixed-metal chain compound, involving two copper(II) and one cobalt(II) ion in the trinuclear unit. Selected bond distances and angles are shown in Table 2 , the repeating unit in Fig. 3.

Complex 4 was synthesised from 2 with cobalt(II) chloride and there are three water molecules in the formula unit. The structure contains a copper part and a cobalt part. In the former the co-ordination sphere around each individual copper(II) is intermediate between square pyramidal and trigonal bipyramidal. ${ }^{9,31}$ Consideration of the distortion from an idealized square-pyramidal geometry illustrates this point. The equatorial plane is defined by two nitrogen atoms $N(1), N(4)$ of the ligands and two chloride atoms, non-bridging $\mathrm{Cl}(2)$ and bridging $\mathrm{Cl}\left(3^{\prime \prime}\right)$, while another bridging chloride ion $\mathrm{Cl}(3)$ occupies the apex of the co-ordination pyramid. Although the $\mathrm{N}(1)-\mathrm{Cu}-\mathrm{N}(4)$ $\left[176.4(4)^{\circ}\right]$ angle is near to the ideal value of $180^{\circ}$ and the $\mathrm{Cl}(3)-\mathrm{Cu}-\mathrm{Cl}\left(3^{\prime \prime}\right)$ [92.61(11)], $\mathrm{Cl}(3)-\mathrm{Cu}-\mathrm{N}(1)$ [91.7(3)] and $\mathrm{Cl}(3)-\mathrm{Cu}-\mathrm{N}(4)\left[91.0(3)^{\circ}\right]$ angles are closer to the expected $90^{\circ}$, $\mathrm{Cl}(2)-\mathrm{Cu}-\mathrm{Cl}\left(3^{\prime \prime}\right)[156.64(14)]$ (ideally $180^{\circ}$ ) and $\mathrm{Cl}(2)-\mathrm{Cu}-\mathrm{Cl}(3)$ $\left[110.62(13)^{\circ}\right]$ (ideally $90^{\circ}$ ) show marked differences from the 


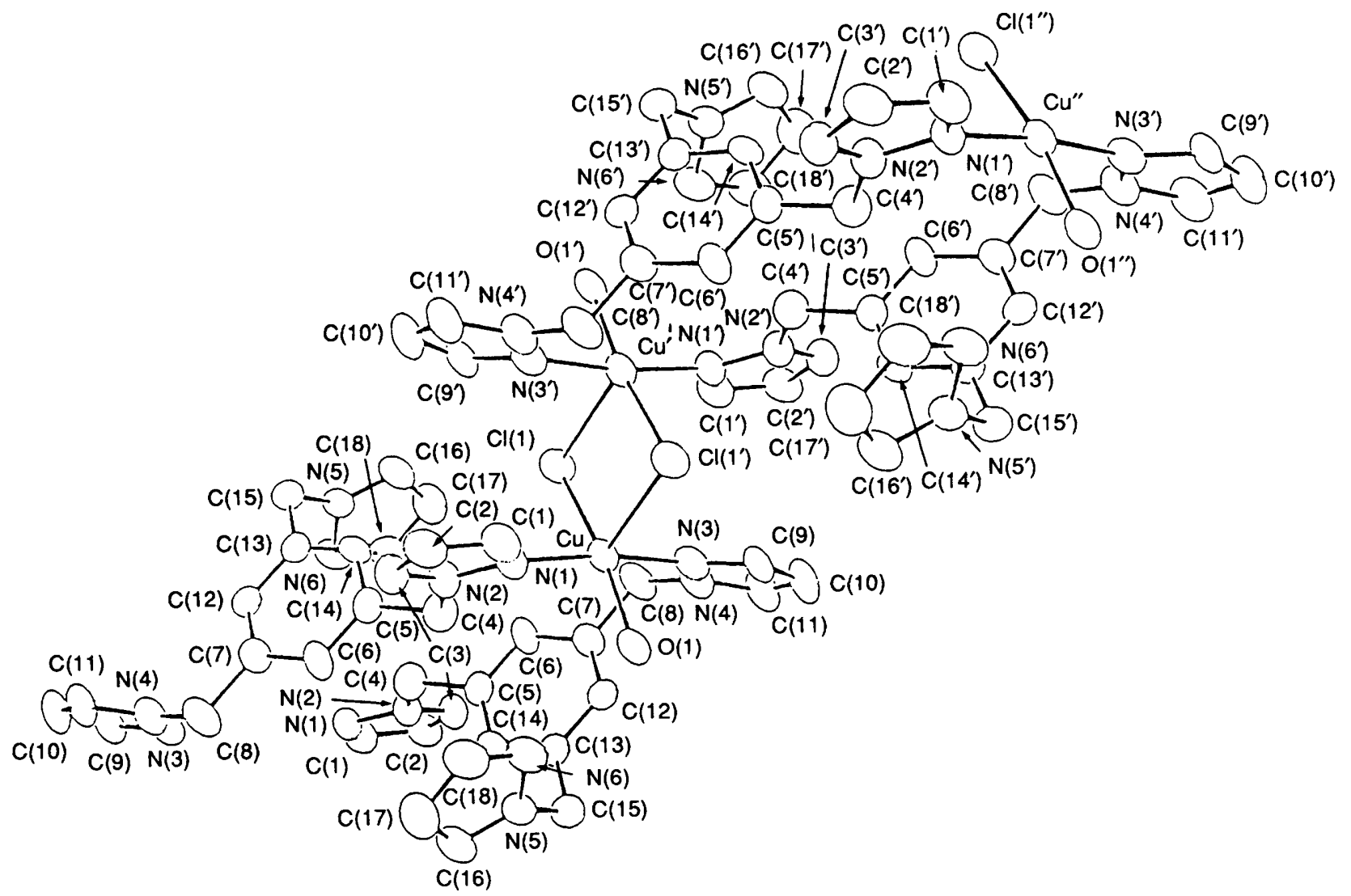

Fig. 2 The repeat unit of complex 2

Table 2 Selected bond distances $(\AA)$ and angles $\left({ }^{\circ}\right)$

\section{Complex 1}

$\mathrm{Cu}-\mathrm{N}(1 \mathrm{~A})$

$\mathrm{Cu}-\mathrm{N}(1 \mathrm{~B})$

$\mathrm{Cu}-\mathrm{O}(3)$

$\mathrm{N}(1 \mathrm{~A})-\mathrm{Cu}-\mathrm{N}(1 \mathrm{~B})$

$\mathrm{N}(1 \mathrm{~A})-\mathrm{Cu}-\mathrm{O}(2)$

$\mathrm{N}(1 \mathrm{~B})-\mathrm{Cu}-\mathrm{O}(1)$

$\mathrm{N}(1 \mathrm{~B})-\mathrm{Cu}-\mathrm{O}(3)$

$\mathrm{O}(1)-\mathrm{Cu}-\mathrm{O}(3)$

$$
\begin{aligned}
& 2.019(4) \\
& 1.988(4) \\
& 2.411(3)
\end{aligned}
$$

$169.89(16)$

$91.37(17)$

$89.05(16)$

$97.78(14)$

$85.69(15)$

Complex 2

$\mathrm{Cu} \cdot . \mathrm{Cu}^{\prime}$

$\mathrm{Cu}-\mathrm{Cl}\left(\mathrm{I}^{\prime}\right)$

$\mathrm{Cu}-\mathrm{N}(3)$

$\mathrm{Cl}(1)-\mathrm{Cu}-\mathrm{Cl}\left(1^{\prime}\right)$

$\mathrm{Cl}(1)-\mathrm{Cu}-\mathrm{N}(1)$

$\mathrm{Cl}(1)-\mathrm{Cu}-\mathrm{O}(1)$

$\mathrm{Cl}\left(1^{\prime}\right)-\mathrm{Cu}-\mathrm{N}(3)$

$\mathrm{N}(1)-\mathrm{Cu}-\mathrm{N}(3)$

$\mathrm{N}(3)-\mathrm{Cu}-\mathrm{O}(1)$

\section{Complex 4}

$\mathrm{Co}-\mathrm{Cl}(1)$

$\mathrm{Cu} \cdot . \mathrm{Cu}^{\prime \prime}$

$\mathrm{Cu}-\mathrm{Cl}\left(3^{\prime \prime}\right)$

$\mathrm{Cu}-\mathrm{N}(1)$

\section{$\mathrm{Cl}(1)-\mathrm{Co}-\mathrm{Cl}\left(1^{\prime}\right)$}

$\mathrm{Cl}\left(1^{\prime}\right)-\mathrm{Co}-\mathrm{N}(6)$

$\mathrm{Cl}(2)-\mathrm{Cu}-\mathrm{Cl}\left(3^{\prime \prime}\right)$

$\mathrm{Cl}(2)-\mathrm{Cu}-\mathrm{N}(1)$

$\mathrm{Cl}(3)-\mathrm{Cu}-\mathrm{Cl}\left(3^{\prime \prime}\right)$

$\mathrm{Cl}(3)-\mathrm{Cu}-\mathrm{N}(4)$

$\mathrm{Cl}\left(3^{\prime \prime}\right)-\mathrm{Cu}-\mathrm{N}(4)$

$\mathrm{Cu}-\mathrm{Cl}(3)-\mathrm{Cu}^{\prime \prime}$

$\begin{array}{cll}3.437(2) & \mathrm{Cu}-\mathrm{Cl}(1) & 2.2764(22) \\ 2.6847(19) & \mathrm{Cu}-\mathrm{N}(1) & 2.009(5) \\ 2.025(6) & \mathrm{Cu}-\mathrm{O}(1) & 1.978(5) \\ & & \\ 92.69(7) & \mathrm{Cu}-\mathrm{Cl}(1)-\mathrm{Cu}^{\prime} & 87.31(6) \\ 91.30(17) & \mathrm{Cl}(1)-\mathrm{Cu}-\mathrm{N}(3) & 93.55(18) \\ 171.73(14) & \mathrm{Cl}\left(1^{\prime}\right)-\mathrm{Cu}-\mathrm{N}(1) & 92.93(16) \\ 92.05(16) & \mathrm{Cl}\left(1^{\prime}\right)-\mathrm{Cu}-\mathrm{O}(1) & 95.06(14) \\ 172.87(23) & \mathrm{N}(1)-\mathrm{Cu}-\mathrm{O}(1) & 85.42(21) \\ 89.07(22) & & \\ & & \\ & & \\ 2.211(4) & \mathrm{Co}-\mathrm{N}(6) & 1.989(11) \\ 3.450(3) & \mathrm{Cu}-\mathrm{Cl}(2) & 2.270(4) \\ 2.390(3) & \mathrm{Cu}-\mathrm{Cl}(3) & 2.599(3) \\ 1.995(9) & \mathrm{Cu}-\mathrm{N}(4) & 1.997(9) \\ & & \\ 124.12(23) & \mathrm{Cl}(1)-\mathrm{Co}-\mathrm{N}(6) & 111.4(3) \\ 103.7(3) & \mathrm{N}(6)-\mathrm{Co}-\mathrm{N}\left(6^{\prime}\right) & 100.1(4) \\ 156.64(14) & \mathrm{Cl}(2)-\mathrm{Cu}-\mathrm{Cl}(3) & 110.62(13) \\ 89.0(3) & \mathrm{Cl}(2)-\mathrm{Cu}-\mathrm{N}(4) & 87.9(3) \\ 92.61(11) & \mathrm{Cl}(3)-\mathrm{Cu}-\mathrm{N}(1) & 91.7(3) \\ 91.0(3) & \mathrm{Cl}\left(3^{\prime \prime}\right)-\mathrm{Cu}-\mathrm{N}(1) & 92.9(3) \\ 89.3(3) & \mathrm{N}(1)-\mathrm{Cu}-\mathrm{N}(4) & 176.4(4) \\ 87.39(11) & & \\ & & \end{array}$

ideal square-pyramidal geometry. A similar comparison can be made for an idealized trigonal-bipyramidal geometry assuming $\mathrm{N}(1), \mathrm{N}(4)$ to be the 'axial' donors and $\mathrm{Cl}(2), \mathrm{Cl}(3), \mathrm{Cl}\left(3^{\prime \prime}\right)$ to form the 'equatorial' plane. Two $\mathrm{Cu}-\mathrm{N}$ distances $[\mathrm{Cu}-\mathrm{N}(1)$ 1.995(9) and $\mathrm{Cu}-\mathrm{N}(4)$ 1.997(9) $\AA]$ are shorter than those of complex 2. Each copper(II) is bridged by two chloride ions and two ligands. The bridging $\mathrm{Cu}_{2} \mathrm{Cl}_{2}$ unit is similar to that of complex 2, the short distance $\mathrm{Cu}-\mathrm{Cl}\left(3^{\prime \prime}\right) 2.390(3) \AA$ being longer than $\mathrm{Cu}-\mathrm{Cl}(1) 2.2764(22) \AA$ in 2 but the long distance $\mathrm{Cu}-\mathrm{Cl}(3)$ $2.599(3) \AA$ is shorter than $\mathrm{Cu}-\mathrm{Cl}\left(1^{\prime}\right) 2.6847(19) \AA$ in 2 . The $\mathrm{Cu} \cdots \mathrm{Cu}^{\prime \prime}$ distance is $3.450(3) \AA$, longer than $\mathrm{Cu} \cdot . \mathrm{Cu}^{\prime}$ $3.437(2) \AA$ of complex 2. The $\mathrm{Cu}-\mathrm{Cl}(3)-\mathrm{Cu}^{\prime \prime}$ angle is $87.39(11)$ and $\mathrm{Cl}(3)-\mathrm{Cu}-\mathrm{Cl}\left(3^{\prime \prime}\right)$ is $92.61(11)^{\circ} ; \mathrm{Cu}, \mathrm{Cu}, \mathrm{Cl}(3)$ and $\mathrm{Cl}\left(3^{\prime \prime}\right)$ are in the same plane.

In the cobalt part the co-ordination sphere around each individual cobalt(II) can be described as distorted tetrahedral. The cobalt(II) is co-ordinated by two pyrazolyl nitrogen atoms of the ligands and two non-bridging chloride ions. The two Co- $\mathrm{N}$ distances are 1.989(11) $\AA$ and the two $\mathrm{Co}-\mathrm{Cl}$ distances are 2.211(4) $\AA$. The $\mathrm{Cl}(1)-\mathrm{Co}-\mathrm{Cl}\left(1^{\prime}\right)[124.12(23)]$ and $\mathrm{N}(6)-$ Co-N $\left(6^{\prime}\right)\left[100.1(4)^{\circ}\right]$ angles differ from tetrahedral geometry (ideally $109.5^{\circ}$ ), signifying $C_{2}$ symmetry of the cobalt(II) centre.

In complex 4 each ligand possesses three donor sites, $N(1)$, $\mathrm{N}(4)$ and $\mathrm{N}(6)$, of the pyrazolyl rings and all are co-ordinated to metal(II) ions, $\mathrm{N}(1)$ and $\mathrm{N}(4)$ to copper(II) and N(6) to cobalt(II). Also each copper(II) is co-ordinated by two bridging chloride ions, $\mathrm{Cl}(3)$ and $\mathrm{Cl}\left(3^{\prime \prime}\right)$, and one non-bridging chloride $\mathrm{Cl}(2)$ and each cobalt(II) is co-ordinated by two non-bridging chlorides, $\mathrm{Cl}(1)$ and $\mathrm{Cl}\left(1^{\prime}\right)$. Complex 4 is a mixed trinuclear $\mathrm{Cu}^{\mathrm{II}} \mathrm{Cu}^{\mathrm{II}} \mathrm{Co}^{\prime \prime}$ infinite network.

Structure of $\left[\mathrm{Cu}_{3} \mathrm{~L}_{2} \mathrm{Cl}_{6}\right] \cdot 2 \mathrm{H}_{2} \mathrm{O}$ 3.--The tricopper(II) unit structure of complex $3\left[\mathrm{CuCu}_{2} \mathrm{~L}_{2} \mathrm{Cl}_{6}\right] \cdot 2 \mathrm{H}_{2} \mathrm{O}$ was believed to be similar to complex $4\left[\mathrm{CoCu}_{2} \mathrm{~L}_{2} \mathrm{Cl}_{6}\right] \cdot 3 \mathrm{H}_{2} \mathrm{O}$. Complexes 3 and 4 are prepared in a similar way from 2 and different metal (II) ions (see Scheme 2). When the IR, UV and elemental analysis properties of these complexes are compared it is concluded that the structure of $\mathbf{3}$ is similar to that of 4 . 
Table 3 Final atomic positional parameters of non-hydrogen atoms

\begin{tabular}{|c|c|c|c|c|c|c|c|}
\hline Atom & $x$ & $y$ & $z$ & Atom & $x$ & $y$ & $z$ \\
\hline \multicolumn{8}{|c|}{ Complex 1} \\
\hline $\mathrm{Cu}$ & $0.29923(5)$ & 0.50000 & $0.21188(5)$ & $C(1 B)$ & $0.4681(5)$ & $0.3972(3)$ & $0.3871(6)$ \\
\hline $\mathrm{N}(1 \mathrm{~A})$ & $0.1885(4)$ & $0.55649(23)$ & $0.0591(4)$ & $\mathrm{C}(2 \mathrm{~B})$ & $0.5030(6)$ & $0.3716(3)$ & $0.5169(6)$ \\
\hline $\mathrm{N}(2 \mathrm{~A})$ & $0.0919(4)$ & $0.60105(21)$ & $0.0629(4)$ & $C(3 B)$ & $0.4401(6)$ & $0.4114(3)$ & $0.5893(5)$ \\
\hline$N(3 A)$ & $-0.0228(4)$ & $0.86604(24)$ & $0.2258(5)$ & $C(4 B)$ & $0.2736(4)$ & $0.5032(4)$ & $0.5317(5)$ \\
\hline$N(4 A)$ & $-0.0348(5)$ & $0.8987(3)$ & $0.1121(5)$ & $\mathrm{C}(5 \mathrm{~B})$ & $0.1280(5)$ & $0.48207(23)$ & $0.4675(5)$ \\
\hline$N(5 A)$ & $-0.5598(4)$ & $0.69435(24)$ & $0.0417(4)$ & $C(6 B)$ & $0.0993(5)$ & $0.4199(3)$ & $0.4089(5)$ \\
\hline$N(6 A)$ & $-0.5901(5)$ & $0.68664(25)$ & $0.1600(5)$ & $\mathrm{C}(7 \mathrm{~B})$ & $-0.0316(5)$ & $0.4025(3)$ & $0.3450(5)$ \\
\hline$C(1 A)$ & $0.2118(5)$ & $0.5645(3)$ & $-0.0612(5)$ & $\mathrm{C}(8 \mathrm{~B})$ & $-0.0586(7)$ & $0.3369(4)$ & $0.2692(7)$ \\
\hline$C(2 A)$ & $0.1320(5)$ & $0.6145(3)$ & $-0.1315(5)$ & $\mathrm{C}(9 \mathrm{~B})$ & $0.0922(9)$ & $0.2474(3)$ & $0.3922(9)$ \\
\hline$C(3 A)$ & $0.0566(5)$ & $0.6362(3)$ & $-0.0509(6)$ & $\mathrm{C}(10 \mathrm{~B})$ & $0.2135(12)$ & $0.2257(4)$ & $0.3977(13)$ \\
\hline$C(4 A)$ & $0.0406(6)$ & $0.6051(3)$ & $0.1828(5)$ & $\mathrm{C}(11 \mathrm{~B})$ & $0.2518(9)$ & $0.2596(4)$ & $0.2970(9)$ \\
\hline$C(5 A)$ & $-0.0749(5)$ & $0.6537(3)$ & $0.1629(5)$ & $C(12 B)$ & $-0.1368(5)$ & $0.4458(4)$ & $0.3460(5)$ \\
\hline$C(6 A)$ & $-0.0526(5)$ & $0.7178(3)$ & $0.2083(5)$ & $C(13 B)$ & $-0.1113(5)$ & $0.5063(4)$ & $0.4050(5)$ \\
\hline$C(7 A)$ & $-0.1585(6)$ & $0.7619(3)$ & $0.1929(6)$ & $C(14 B)$ & $0.0236(5)$ & $0.5254(3)$ & $0.4669(5)$ \\
\hline $\mathrm{C}(8 \mathrm{~A})$ & $-0.1381(6)$ & $0.8313(3)$ & $0.2480(7)$ & $C(15 B)$ & $-0.2274(6)$ & $0.5531(4)$ & $0.3994(6)$ \\
\hline$C(9 A)$ & $0.1056(7)$ & $0.8657(4)$ & $0.3059(7)$ & $\mathrm{C}(16 \mathrm{~B})$ & $-0.1890(5)$ & $0.5514(4)$ & $0.6527(6)$ \\
\hline$C(10 A)$ & $0.1796(7)$ & $0.9001(4)$ & $0.2361(9)$ & $\mathrm{C}(17 \mathrm{~B})$ & $-0.2688(6)$ & $0.5638(4)$ & $0.7363(5)$ \\
\hline$C(11 A)$ & $0.0909(7)$ & $0.9187(4)$ & $0.1172(7)$ & $\mathrm{C}(18 \mathrm{~B})$ & $-0.3952(5)$ & $0.5745(3)$ & $0.6474(6)$ \\
\hline$C(12 A)$ & $-0.2881(5)$ & $0.7404(3)$ & $0.1280(6)$ & $O(1)$ & $0.3878(3)$ & $0.57830(18)$ & $0.3004(3)$ \\
\hline$C(13 A)$ & $-0.3151(5)$ & $0.6760(3)$ & $0.0832(5)$ & $O(2)$ & $0.2117(4)$ & $0.42187(22)$ & $0.1281(4)$ \\
\hline$C(14 A)$ & $-0.2059(5)$ & $0.6326(3)$ & $0.1024(5)$ & $O(3)$ & $0.4850(6)$ & $0.49327(23)$ & $0.1118(3)$ \\
\hline$C(15 A)$ & $-0.457 \mathrm{l}(6)$ & $0.6535(3)$ & $0.0106(6)$ & $\mathrm{O}(4)$ & $0.4272(6)$ & $0.4418(5)$ & $-0.0930(5)$ \\
\hline$C(16 A)$ & $-0.6174(6)$ & $0.7481(3)$ & $-0.0238(6)$ & $O(5)$ & $0.5492(9)$ & $0.3870(3)$ & $0.0909(7)$ \\
\hline$C(17 A)$ & $-0.6905(6)$ & $0.7777(3)$ & $0.0540(7)$ & $O(6)$ & $0.6495(6)$ & $0.4670(3)$ & $0.0057(7)$ \\
\hline$C(18 A)$ & $-0.6693(6)$ & $0.7371(3)$ & $0.1652(6)$ & $O(7)$ & $0.6191(9)$ & $0.1990(4)$ & $0.5141(7)$ \\
\hline$N(1 B)$ & $0.3838(4)$ & $0.44879(21)$ & $0.3787(4)$ & $\mathrm{O}(8)$ & $0.6668(9)$ & $0.1639(4)$ & $0.3269(6)$ \\
\hline$N(2 B)$ & $0.3710(4)$ & $0.45698(22)$ & $0.5053(4)$ & $O(9)$ & $0.7040(11)$ & $0.2710(3)$ & $0.3916(11)$ \\
\hline$N(3 B)$ & $0.0541(6)$ & $0.2935(3)$ & $0.2961(5)$ & $O(10)$ & $0.8247(8)$ & $0.1931(8)$ & $0.4922(14)$ \\
\hline$N(4 B)$ & $0.1549(6)$ & $0.3029(3)$ & $0.2369(6)$ & $\mathrm{Cl}(1)$ & $0.52609(15)$ & $0.44766(8)$ & $0.02286(15)$ \\
\hline$N(5 B)$ & $-0.2650(4)$ & $0.55475(24)$ & $0.5251(4)$ & $\mathrm{Cl}(2)$ & $0.69968(16)$ & $0.20874(8)$ & $0.42853(14)$ \\
\hline$N(6 B)$ & $-0.3953(4)$ & $0.5703(3)$ & $0.5208(4)$ & & & & \\
\hline \multicolumn{8}{|c|}{ Complex 2} \\
\hline $\mathrm{Cu}$ & $0.89085(7)$ & $0.08663(7)$ & $0.00398(6)$ & $C(10)$ & $1.0966(7)$ & $0.2212(7)$ & $0.2406(5)$ \\
\hline $\mathrm{Cl}(1)$ & $0.89573(16)$ & $-0.07481(14)$ & $0.04306(13)$ & $C(11)$ & $1.0109(7)$ & $0.1771(7)$ & $0.2758(4)$ \\
\hline$N(1)$ & $0.7920(5)$ & $0.0564(4)$ & $-0.1229(4)$ & $C(12)$ & $0.6971(6)$ & $0.1860(5)$ & $0.1250(4)$ \\
\hline$N(2)$ & $0.6774(5)$ & $0.0169(4)$ & $-0.1474(3)$ & $\mathrm{C}(13)$ & $0.4197(6)$ & $-0.2159(5)$ & $-0.0742(4)$ \\
\hline$N(3)$ & $0.9753(5)$ & $0.1306(5)$ & $0.1319(4)$ & $C(14)$ & $0.5170(6)$ & $-0.1513(5)$ & $-0.0650(4)$ \\
\hline$N(4)$ & $0.9387(5)$ & $0.1226(5)$ & $0.2101(4)$ & $C(15)$ & $0.4354(6)$ & $-0.3122(5)$ & $-0.0252(4)$ \\
\hline$N(5)$ & $0.4662(5)$ & $-0.2974(4)$ & $0.0726(4)$ & $C(16)$ & $0.5763(7)$ & $-0.2957(6)$ & $0.1312(5)$ \\
\hline$N(6)$ & $0.3790(5)$ & $-0.2652(5)$ & $0.1129(4)$ & $\mathrm{C}(17)$ & $0.5625(8)$ & $-0.2621(7)$ & $0.2126(5)$ \\
\hline$C(1)$ & $0.8274(6)$ & $0.0630(6)$ & $-0.2001(5)$ & $\mathrm{C}(18)$ & $0.4389(7)$ & $-0.2446(6)$ & $0.1977(5)$ \\
\hline$C(2)$ & $0.7378(7)$ & $0.0282(6)$ & $-0.2725(5)$ & $O(1)$ & $0.8609(4)$ & $0.2258(4)$ & $-0.0315(3)$ \\
\hline$C(3)$ & $0.6418(6)$ & $0.0013(6)$ & $-0.2365(5)$ & $\mathrm{Cl}(2)$ & $0.25345(20)$ & $0.42211(18)$ & $0.06404(15)$ \\
\hline$C(4)$ & $0.6045(6)$ & $0.0148(6)$ & $-0.0801(5)$ & $O(2)$ & $0.2501(10)$ & $0.3255(6)$ & $0.0402(9)$ \\
\hline$C(5)$ & $0.5003(6)$ & $-0.0587(5)$ & $-0.1017(4)$ & $O(3)$ & $0.3487(12)$ & $0.4415(12)$ & $0.1315(9)$ \\
\hline$C(6)$ & $0.3852(6)$ & $-0.0280(6)$ & $-0.1501(4)$ & $\mathrm{O}(4)$ & $0.2827(12)$ & $0.4666(8)$ & $-0.0033(7)$ \\
\hline$C(7)$ & $0.7142(6)$ & $0.0964(5)$ & $0.1629(4)$ & $O(5)$ & $0.1577(9)$ & $0.4562(10)$ & $0.0868(9)$ \\
\hline $\mathrm{C}(8)$ & $0.8385(6)$ & $0.0599(6)$ & $0.2184(5)$ & $O(6)$ & $0.9170(6)$ & $0.3828(5)$ & $0.0813(5)$ \\
\hline$C(9)$ & $1.0711(6)$ & $0.1913(6)$ & $0.1510(5)$ & & & & \\
\hline \multicolumn{8}{|c|}{ Complex 4} \\
\hline Co & $\frac{1}{2}$ & $0.38098(11)$ & $\frac{1}{4}$ & $C(6)$ & $0.1058(14)$ & $0.2010(5)$ & $0.0501(4)$ \\
\hline $\mathrm{Cu}$ & $-0.02221(21)$ & $0.43342(7)$ & $-0.03193(5)$ & $\mathrm{C}(7)$ & $0.1339(15)$ & $0.2645(5)$ & $0.0603(4)$ \\
\hline $\mathrm{Cl}(1)$ & $0.2707(7)$ & $0.42777(23)$ & $0.20950(17)$ & $C(8)$ & $0.0601(18)$ & $0.3105(6)$ & $0.0233(4)$ \\
\hline $\mathrm{Cl}(2)$ & $-0.1693(5)$ & $0.36688(15)$ & $-0.08367(12)$ & $C(9)$ & $-0.2236(17)$ & $0.3200(6)$ & $0.0644(4)$ \\
\hline $\mathrm{Cl}(3)$ & $-0.2090(4)$ & $0.53183(13)$ & $-0.02706(11)$ & $C(10)$ & $-0.3543(17)$ & $0.3638(6)$ & $0.0658(4)$ \\
\hline$N(1)$ & $0.3984(12)$ & $0.0337(4)$ & $0.0857(3)$ & $C(11)$ & $-0.2990(15)$ & $0.4085(5)$ & $0.0374(4)$ \\
\hline $\mathrm{N}(2)$ & $0.2341(13)$ & $0.0484(4)$ & $0.0996(3)$ & $\mathrm{C}(12)$ & $0.2163(16)$ & $0.2820(5)$ & $0.1042(4)$ \\
\hline $\mathrm{N}(3)$ & $-0.1035(13)$ & $0.3394(4)$ & $0.0368(3)$ & $C(13)$ & $0.2737(15)$ & $0.2374(5)$ & $0.1388(4)$ \\
\hline $\mathrm{N}(4)$ & $-0.1470(12)$ & $0.3955(4)$ & $0.0198(3)$ & $C(14)$ & $0.2449(14)$ & $0.1778(5)$ & $0.1277(4)$ \\
\hline $\mathrm{N}(5)$ & $0.5491(12)$ & $0.2709(4)$ & $0.1884(3)$ & $C(15)$ & $0.3555(16)$ & $0.2565(6)$ & $0.1875(4)$ \\
\hline$N(6)$ & $0.6170(13)$ & $0.3233(5)$ & $0.2089(3)$ & $C(16)$ & $0.6723(18)$ & $0.2349(7)$ & $0.1751(5)$ \\
\hline$C(1)$ & $0.4673(18)$ & $-0.0043(5)$ & $0.1191(4)$ & $C(17)$ & $0.8335(18)$ & $0.2636(8)$ & $0.1835(5)$ \\
\hline$C(2)$ & $0.3482(21)$ & $-0.0139(6)$ & $0.1532(4)$ & $C(18)$ & $0.7926(19)$ & $0.3169(7)$ & $0.2041(4)$ \\
\hline$C(3)$ & $0.2040(19)$ & $0.0205(6)$ & $0.1403(4)$ & $O(1)$ & $\frac{1}{2}$ & $0.1234(9)$ & $\frac{1}{4}$ \\
\hline$C(4)$ & $0.1209(16)$ & $0.0933(5)$ & $0.0725(4)$ & $O(2)$ & $0.793(4)$ & $0.0823(12)$ & $0.2172(8)$ \\
\hline$C(5)$ & $0.1601(15)$ & $0.1588(5)$ & $0.0840(4)$ & & & & \\
\hline
\end{tabular}


Table 4 Values of $\tau$ for selected copper(II) complexes

\begin{tabular}{|c|c|c|c|c|c|}
\hline Complex $^{a}$ & $\beta /{ }^{\circ}$ & $\alpha /^{\circ}$ & $\tau$ & Geometry ${ }^{b}$ & Ref. \\
\hline$[\mathrm{Cu}(\mathrm{bbes})(\mathrm{acac})]^{+}$ & 171.4 & 170.8 & 0.01 & $S P Y$ & 36 \\
\hline$\left[\mathrm{Cu}_{2} \mathrm{~L}_{2} \mathrm{Cl}_{2}\left(\mathrm{H}_{2} \mathrm{O}\right)_{2}\right]^{2+}$ & 172.87 & 171.73 & 0.02 & $S P Y$ & This work \\
\hline$\left[\mathrm{Cu}(\text { pdto })\left(\mathrm{ClO}_{4}\right)\right]^{+}$ & 170.1 & 162.8 & 0.12 & $S P Y$ & 34 \\
\hline$\left[\mathrm{CuL}_{2}\left(\mathrm{ClO}_{4}\right)\left(\mathrm{H}_{2} \mathrm{O}\right)_{2}\right]^{+}$ & 178.76 & 169.89 & 0.15 & $S P Y$ & This work \\
\hline$[\mathrm{Cu}(\text { tpea }) \mathrm{Cl}]^{+}$ & 71.1 & 159.8 & 0.19 & $S P Y$ & 35 \\
\hline$\left[\mathrm{Cu}(\mathrm{bbes})(\mathrm{MeOH})\left(\mathrm{H}_{2} \mathrm{O}\right)\right]^{2+}$ & 174.6 & 158.6 & 0.27 & $S P Y$ & 36 \\
\hline$[\mathrm{Cu}(\mathrm{fptc})(\mathrm{bipy})]^{+}$ & 74.9 & 156.9 & 0.3 & $S P Y, T B P Y^{c}$ & 9 \\
\hline$\left[\mathrm{Cu}_{2} \mathrm{CoL}_{2} \mathrm{Cl}_{6}\right]$ & 176.4 & 156.64 & 0.33 & $S P Y, T B P Y$ & This wor \\
\hline$[\mathrm{Cu}(\mathrm{bbdh}) \mathrm{Cl}]$ & 165.9 & 142.18 & 0.39 & $T B P Y$ & 37 \\
\hline$\left[\left\{\mathrm{Cu}(\text { teen }) \mathrm{Cl}_{2}\right\}_{2}\right]$ & 174.91 & 145.69 & 0.49 & $T B P Y$ & 2 \\
\hline$\left[\mathrm{Cu}(\mathrm{bbtb})\left(\mathrm{H}_{2} \mathrm{O}\right)\right]^{2+}$ & 175.2 & 136.8 & 0.64 & $T B P Y$ & 38 \\
\hline$\left[\mathrm{Cu}(\text { bipy })_{2}(\mathrm{tu})\right]^{2+}$ & 169.6 & 119.9 & 0.83 & $T B P Y$ & 39 \\
\hline$\left[\mathrm{CuCl}_{5}\right]^{3}$ & 180 & 120 & 1.00 & $T B P Y$ & 40 \\
\hline
\end{tabular}

${ }^{a}$ bbdh $=1,6$-Bis(benzimidazol-2-yl)-2,5-dithiahexane; teen $=N, N, N^{\prime}$-triethylethylenediamine; $b$ btb $=1,2$-bis(benzimidazol-2-ylmethylthio)ben-

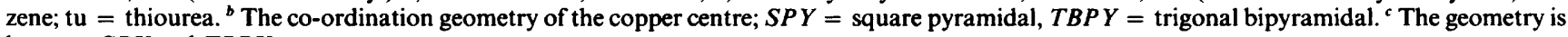
between $S P Y$ and $T B P Y$.

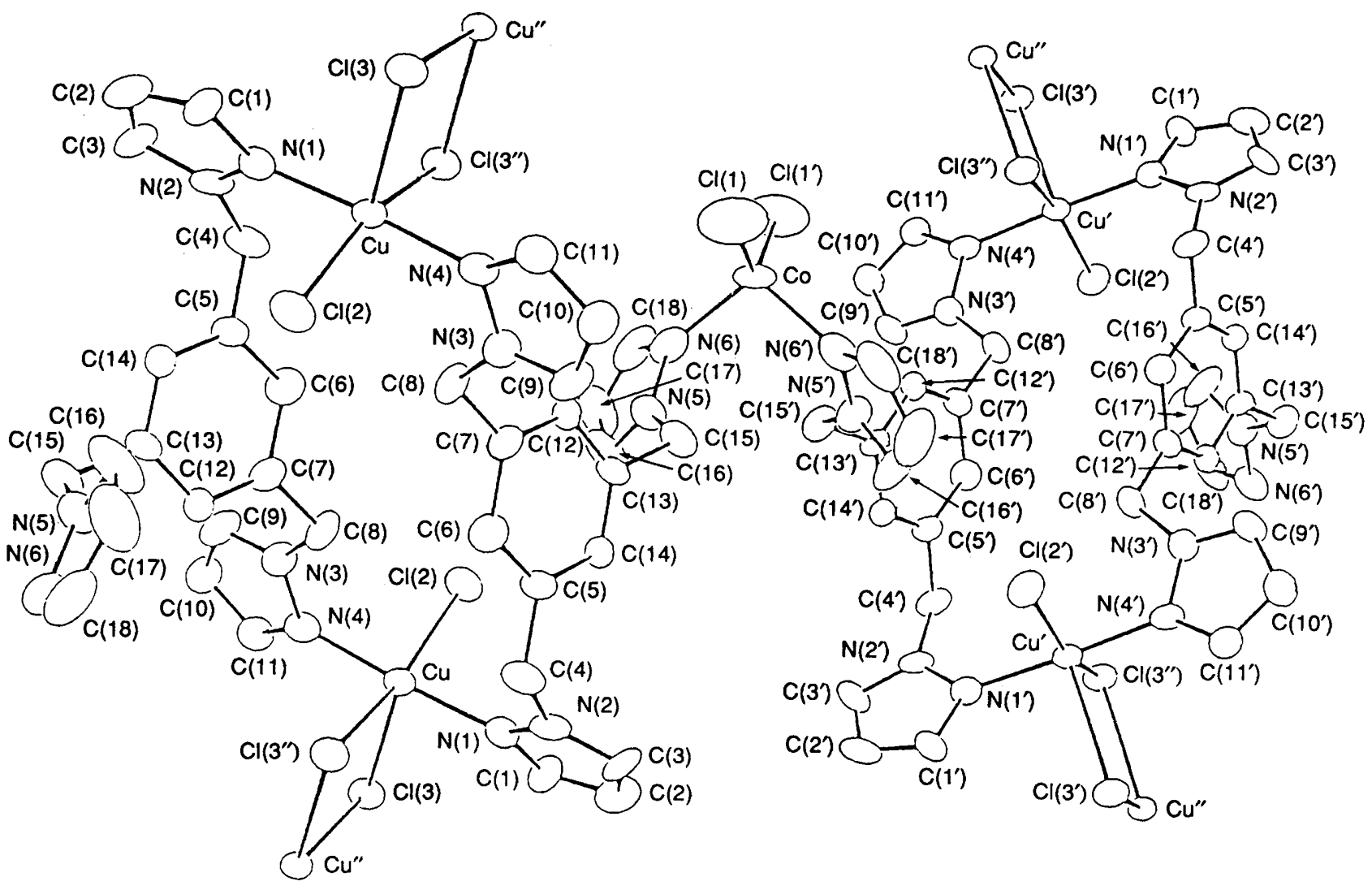

Fig. 3 The repeat unit of complex 4

As complexes 1, 2 and 4 comprise a series which contains a range of structural types intermediate between the idealized square-pyramidal and trigonal-bipyramidal extremes it seems desirable to systematize these geometries by using a structural index. In a five-co-ordinate system such as that represented on the following page, ideally square-pyramidal geometry is associated with $\alpha=\beta=180^{\circ}$, for $A$ as the axial ligand ( $\beta$ is the greater of the basal angles, B-M-C). For perfectly trigonalbipyramidal geometry, $\alpha=120^{\circ}$ and $\mathrm{B}-\mathrm{M}-\mathrm{C}$ is the principal axis. The geometric parameter $\tau=(\beta-\alpha) / 60,0$ for a $C_{4 v}$ and 1 for a $D_{3 h}$ co-ordination polyhedron, as defined by Addison et al. ${ }^{32}$

Table 4 shows complexes 1,2 and 4 to have $\tau$ values of $0.15,0.02$ and 0.33 , and compares these values with structural results for complexes with related geometries. For $[\mathrm{Cu}(\mathrm{bbes})-$ $(\mathrm{acac})]^{+}[$bbes $=$bis(2-benzimidazolylethyl) sulfide, acac $=$ acetylacetonate], ${ }^{36} \tau=0.01$, so the geometry is very close to being perfectly square pyramidal, and $\left[\mathrm{CuCl}_{5}\right]^{3-40} \tau=1.00$, is perfectly trigonal bipyramidal. The other $\tau$ values are in the range 0.01-1.00 which reveals the 'distortion' of their geometries. For complex $2,\left[\mathrm{Cu}_{2} \mathrm{~L}_{2} \mathrm{Cl}_{2}\left(\mathrm{H}_{2} \mathrm{O}\right)_{2}\right]^{2+}, \tau$ is very small $(0.02)$ and the geometry is slightly distorted square pyramidal. The complex $\left[\mathrm{Cu}(\text { pdto })\left(\mathrm{ClO}_{4}\right)\right]^{+}[$pdto $=1,8$-bis(2-pyridyl)-3,6-dithiaoctane $]{ }^{34}\left[\mathrm{CuL}_{2}\left(\mathrm{ClO}_{4}\right)_{2}\left(\mathrm{H}_{2} \mathrm{O}\right)_{2}\right] 1$ and $[\mathrm{Cu}(\text { tpea }) \mathrm{Cl}]^{+} \quad$ tpea $=\operatorname{tris}[2-(2-\text { pyridyl)ethyl }] \text { amine }\}^{35}$ are about $10-20 \%$ distorted toward the trigonal-bipyramidal state as judged by the $\tau$ values. Complex $4,\left[\mathrm{Cu}_{2} \mathrm{CoL}_{2} \mathrm{Cl}_{6}\right]$, has a larger $\tau$ value (0.33), however the value of $\alpha\left[156.64^{\circ}\right.$, the angle $\left.\mathrm{Cl}(2)-\mathrm{Cu}-\mathrm{Cl}\left(3^{\prime \prime}\right)\right]$ is between 180 (ideal square pyramidal) and $120^{\circ}$ (ideal trigonal bipyramidal) which shows that the geometry is similar to that of $[\mathrm{Cu}(\mathrm{fptc})(\mathrm{bipy})]^{+}(\mathrm{Hfptc}=$ 2 -formylpyridine thiosemicarbazone, bipy $=2,2^{\prime}$-bipyridine) ${ }^{9}$ 


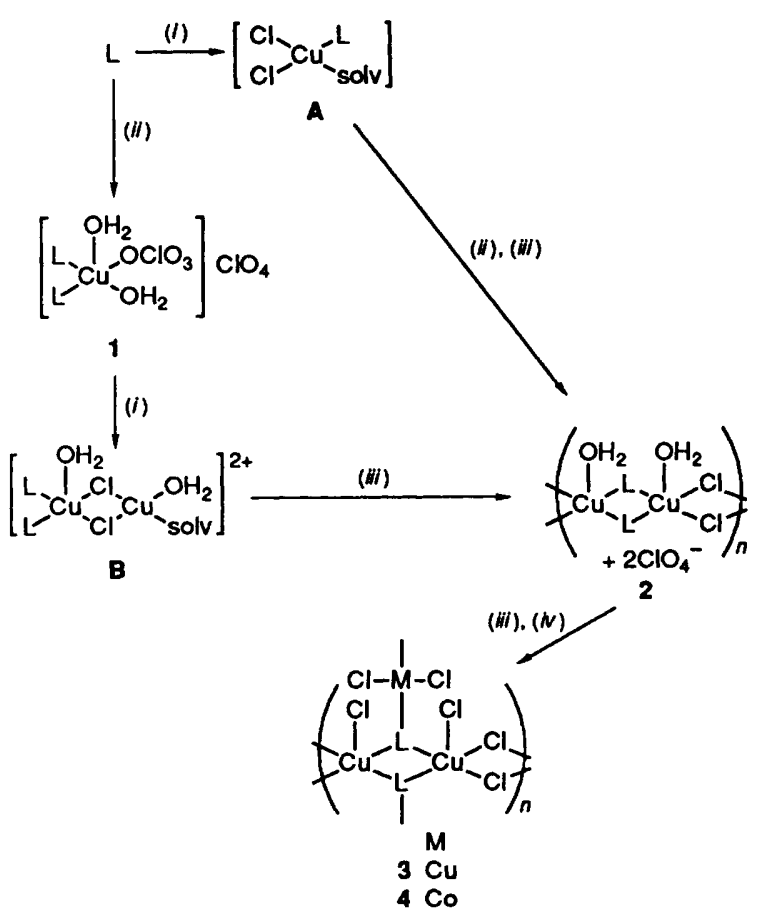

Scheme 2 solv = Solvent. (i) $\mathrm{CuCl}_{2} ;$ (ii) $\mathrm{Cu}\left(\mathrm{ClO}_{4}\right)_{2}$; (iii) polymerization; (iv) $\mathrm{MCl}_{2}(\mathrm{M}=\mathrm{Cu}$ or $\mathrm{Co})$

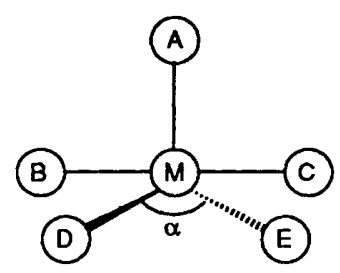

Spectroscopy.--In the IR spectra the $\mathbf{C}-\mathbf{H}$ stretching vibrations of the pyrazolyl groups in complexes $1-4$ are at 3115 , 3119,3116 and $3127 \mathrm{~cm}^{-1}$, and the $\mathrm{C}=\mathrm{N}$ stretching vibrations at $1512,1515,1514$ and $1513 \mathrm{~cm}^{-1}$, respectively. Complex 2 shows a strong peak at $1074 \mathrm{~cm}^{-1}$ for the perchlorate ion which has a regular tetrahedral structure and belongs to the point group $T_{d}$. Complex 1 has two perchlorate ions. One is a counter anion with a peak at $1089 \mathrm{~cm}^{-1}$. The other is bonded through one oxygen $\left(\mathrm{O}^{*}\right)$ and the original $T_{d}$ symmetry is lowered to $C_{3 v}$, with two strong absorption peaks at $1150\left(\mathrm{Cl}-\mathrm{O}^{*}\right)$ and $1051 \mathrm{~cm}^{-1}\left(\mathrm{ClO}_{3}\right){ }^{41}$

In the UV spectra the pyrazolyl group absorption maxima are at $223,224,241$ and $238 \mathrm{~nm},{ }^{42}$ those of the benzene group are at $269,268,270$ and $267 \mathrm{~nm}$ and there is a shoulder at about $318,332,322$ and $320 \mathrm{~nm}$ for complexes 1-4 (see Experimental section).

The X-band polycrystalline ESR spectra and magnetic moments of the complexes were measured at room temperature. The ESR spectrum of complex 1 is similar to that of $\left[\mathrm{Cu}(\mathrm{bmdhp})\left(\mathrm{H}_{2} \mathrm{O}\right)\left(\mathrm{ClO}_{4}\right)\right]_{2}{ }^{32}[\mathrm{bmdhp}=1,7-\mathrm{bis}(N$-methylbenzimidazol-2-yl)-2,6-dithiaheptane] and complex 2 shows an axial signal. ${ }^{43}$ The $g$ values $\left(g_{\|}=2.297, g_{\perp}=2.066\right.$ for complex $1, g_{\|}=2.304, g_{\perp}=2.056$ for 2) are consistent with a square-pyramidal co-ordination sphere for the copper(II) and the single unpaired electron is located in an essentially $d_{x^{2}-y^{2}}$ orbital. The magnetic moment of complex $1\left(\mu_{\mathrm{eff}}=1.87\right)$ can be regarded as normal and 2 has a value $\left(\mu_{\text {eff }}=1.86\right.$ per copper), relatively near to the spin-only value of 1.73 for the free copper(II) ion. ${ }^{43}$ This indicates the absence of antiferro- magnetic coupling between the two copper(II) ions of the bridging $\mathrm{CuCl}_{2} \mathrm{Cu}$ unit. ${ }^{44}$ The ESR spectra of complexes 3 and 4 show rhombic signals with three $g$ values ${ }^{43}\left(g_{1}=2.050\right.$, $g_{2}=2.112, g_{3}=2.200$ for 3 and $g_{1}=2.054, g_{2}=2.128$ $g_{3}=2.262$ for 4$)$. The magnetic moments are low $\left(\mu_{\text {eff }}=3.30\right.$ per unit of 3, 3.81 per unit of 4). The total magnetic moments of complexes 3 and 4 can be obtained by the equation: $\chi_{M}^{\prime}($ per unit $)=\chi_{M}^{\prime}[$ non-bridged metal(II) $(\mathrm{Cu}, \mathrm{Co})]+\chi_{M}^{\prime}-$ [bridged copper(II) $\left.\left(\mathrm{CuCl}_{2} \mathrm{Cu}\right)\right]$. Because the $\mathrm{CuCl}_{2} \mathrm{Cu}$ units of complexes 3 and 4 are similar to that of complex $2, \chi_{M}{ }^{\prime}$ for 2 can be substituted for the term $\chi_{M}^{\prime}$ [bridged copper(II) $\left(\mathrm{CuCl}_{2} \mathrm{Cu}\right)$ ] in each. Values of $\chi_{M}{ }^{\prime}$ (and $\mu_{\text {eff }}$ ) for non-bridged metal(II) (Co, $\mathrm{Cu}$ ) can thus be found. For complex 3, $\mu_{\text {eff }}$ for the non-bridged copper(II) is $\approx 1.90$, in accord with a $\mathrm{d}^{9}$ configuration. ${ }^{44}$

Non-bridged $\mathrm{Co}^{11}$ ( $\mathrm{d}^{7}$ configuration) can show two spin states, high spin $\left(S=\frac{3}{2}\right)$ for which $\mu_{\text {eff }}$ is in the range $4.1-5.2^{45}$ and low spin $\left(S=\frac{1}{2}\right)$ for which $\mu_{\text {eff }}$ is similar to that of [Co(NO)$\left.\left\{\mathrm{N}\left(\mathrm{CH}_{2} \mathrm{CH}_{2} \mathrm{PPh}_{2}\right)_{3}\right\}\right] \mathrm{BPh}_{4} \quad\left(\mu_{\text {eff }}=1.98\right),{ }^{46}\left[\mathrm{Co}(\mathrm{dman})_{2} \mathrm{I}\right] \mathrm{I}$ [dman $=1,8$-bis (dimethylarsino)naphthalene $] \quad\left(\mu_{\text {eff }}=2.06\right)$, $\left[\mathrm{Co}(\text { dman })_{2} \mathrm{I}\right] \mathrm{ClO}_{4} \quad\left(\mu_{\text {eff }}=1.97\right),{ }^{47} \quad\left[\mathrm{Co}(\mathrm{NCS})_{2}\left(\mathrm{PMe}_{3}\right)_{2}\right]$ $\left(\mu_{\text {eff }}=2.15\right)$ and $\left[\mathrm{CoBr}_{2}\left(\mathrm{PMe}_{3}\right)_{3}\right]\left(\mu_{\text {eff }}=2.20\right)^{48}$ In complex $4 \mu_{\text {eff }}=2.47$ for $\mathrm{Co}^{\text {II }}$ i.e. towards the low spin regime.

\section{Acknowledgements}

This work was supported by the National Science Council, Taiwan, Republic of China.

\section{References}

1 M. G. B. Drew, M. McCann and S. M. Nelson, J. Chem. Soc., Dalton Trans., 1981, 1868

2 W. E. Marsh, K. C. Patel, W. E. Hatfield and D. J. Hodgson, Inorg. Chem., 1983, 22, 511.

3 W. C. Velthuizen, J. G. Haasnoot, A. J. Kinneging, F. J. Rietmeijer and J. Reedijk, J. Chem. Soc., Chem. Commun., 1983, 1366.

4 M. Kwiatkowski, E. Kwiatkowski, A. Olechnowicz and G. Bandoli, Inorg. Chim. Acta, 1991, 182, 117.

5 F. S. Keij, R. A. G. de Graaff, J. G. Haasnoot, J. Reedijk and E. Pedersen, Inorg. Chim. Acta, 1989, 156, 65.

6 S. K. Mandal, L. K. Thompson, K. Nag, J. P. Charland and E. J. Gabe, Inorg. Chem., 1987, 26, 1391.

7 M. Munakata, M. Maekawa, S. Kitagawa, M. Adachi and H. Masuda, Inorg. Chim. Acta, 1990, 167, 181.

8 S. Kitagawa, S. Matsuyama, M. Munakata, N. Osawa and H. Masuda, J. Chem. Soc., Dalton Trans., 1991, 1717.

9 E. W. Ainscough, A. M. Brodie, J. D. Ranford and J. M. Waters, J. Chem. Soc., Dalton Trans., 1991, 1737.

10 V. McKee and S. S. Tandon, J. Chem. Soc., Dalton Trans., 1991, 221 .

11 T. Kawato, H. Koyama, H. Kanatomi and Y. Muramoto, Inorg. Chim. Acta, 1991, 183, 107

12 D. E. Fenton and S. E. Gayda, J. Chem. Soc., Dalton Trans., 1977, 2109.

13 D. E. Fenton, S. E. Gayda, U. Casellato, P. A. Vigato and M. Vidali, Inorg. Chim. Acta, 1978, 27, 9.

14 N. A. Bailey, S. F. Davison, J. R. Elliot, D. E. Fenton, E. Godbehere, S. K. Holdroyd and C. R. de Barbarin, J. Chem. Soc., Dalton Trans., 1984, 1073.

15 J. Powell and C. J. May, J. Am. Chem. Soc., 1982, 104, 2636.

16 F. C. G. M. van Veggel, M. Bos, S. Harkema, W. Verboom and D. N. Reinhoudt, Angew. Chem., Int. Ed. Engl., 1989, 28, 746.

17 K. D. Karlin, R. W. Cruse and Y. Gultneh, J. Chem. Soc., Chem. Commun., 1987, 599; J. E. Pate, R. W. Cruse, K. D. Karlin and E. I. Solomon, J. Am. Chem. Soc., 1987, 109, 2624; K. D. Karlin, R. W. Cruse, Y. Gultneh, A. Farooq, J. C. Hayes and J. Zubieta, J. Am. Chem. Soc., 1987, 109, 2668; K. D. Karlin, M. S. Haka, R. W. Cruse, G. J. Meyer, A. Farooq, Y. Gultneh, J. C. Hayes and J. Zubieta, J. Am. Chem. Soc., 1988, 110, 1196; N. J. Blackburn, R. W. Strange, A. Farooq, M. S. Haka and K. D. Karlin, J. Am. Chem. Soc., 1988, 110, 4263; K. D. Karlin, P. Ghosh, R. W. Cruse, A. Farooq, Y. Gultneh, R. R. Jacobson, N. J. Blackburn, R. W. Strange and J. Zubieta, J. Am. Chem. Soc., 1988, 110, 6769; P. P. Paul, Z. Tyeklár, R. R. Jacobson and K. D. Karlin, J. Am. Chem. Soc., 1991, 113, 5322. 
18 T. N. Sorrell, C. C. Shen and C. J. O'Connor, Inorg. Chem., 1987, 26, 1755; T. N. Sorrell, M. L. Garrity and D. J. Ellis, Inorg. Chim. Acta, 1989, 166, 71; T. N. Sorrell and V. A. Vankai, Inorg. Chem., 1990, 29 , 1687; T. N. Sorrell, V. A. Vankai and M. L. Garrity, Inorg. Chem., 1991, 30, 207; T. N. Sorrell and M. L. Garrity, Inorg. Chem., 1991, 30, 210.

19 H. Adams, N. A. Bailey, M. J. S. Dwyer, D. E. Fenton, P. C. Hellier and P. D. Hempstead, J. Chem. Soc., Chem. Commun., 1991, 1297; S. M. Nelson, F. Esho, A. Lavery and M. G. B. Drew, J. Am. Chem. Soc., 1983, 105, 5693; N. Kitajima, T. Koda, S. Hashimoto, T. Kitagawa and Y. Moro-oka, J. Am. Chem. Soc., 1991, 113, 5664; N. Kitajima, K. Fujisawa, C. Fujimoto, Y. Moro-oka, S. Hashimoto, T. Kitagawa, K. Toriumi, K. Tatsumi and A. Nakamura, J. Am. Chem. Soc., 1992, 114, 1277.

20 M. J. Gunter, L. N. Mander and K. S. Murray, J. Chem. Soc., Chem. Commun., 1991, 799.

21 M. J. Gunter, L. N. Mander, K. S. Murray and P. E. Clark, J. Am. Chem. Soc., 1981, 103, 6784.

22 D. E. Fenton, U. Casellato, P. A. Vigato and M. Vidali, Inorg. Chim. Acta, 1982, 62, 57.

23 D. A. Wrobleski and T. B. Rauchfuss, J. Am. Chem. Soc., 1982, $104,2314$.

24 A. Carroy and J. M. Lehn, J. Chem. Soc., Chem. Commun., 1986, 1232.

25 J. A. Roe, R. Peoples, D. M. Scholler and J. S. Valentine, J. Am. Chem. Soc., 1990, 112, 1538.

26 P. Chaudhuri, M. Winter, B. P. C. Della Védova, E. Bill, A. Trautwein, S. Gehring, P. Fleischhauer, B. Nuber and J. Weiss, Inorg. Chem., 1991, 30, 2148.

27 C.-T. Chen, W.-K. Chang, S.-C. Sheu, G.-H. Lee, T.-I. Ho, Y.-C. Lin and Y. Wang, J. Chem. Soc., Dalton Trans., 1991, 1569.

28 R. R. Hree, T. Enkoji and J. P. Dailey, J. Am. Chem. Soc., 1957, 79, 4230.

29 E. J. Gabe, Y. Le Page, P. S. White and F. L. Lee, Acta Crystallogr., Sect. $A, 1987,43$, S294.

30 International Tables for X-Ray Crystallography, Kynoch Press, Birmingham, 1974, vol. 4.

31 J. T. Blanchett and R. D. Willett, Inorg. Chem., 1988, $27,843$.
32 A. W. Addison, T. N. Rao, J. Reedijk, J. van Rijn and G. C. Verschoor, J. Chem. Soc., Dalton Trans., 1984, 1349.

33 O. P. Anderson and A. B. Packard, Inorg. Chem., 1980, 19, 2941

34 G. R. Brubaker, J. N. Brown, M. K. Yoo, B. A. Kinset, T. M. Kutchan and E. A. Mottel, Inorg. Chem., 1979, 18, 299.

35 K. D. Karlin, J. C. Hayes, S. Juen, J. P. Hutchinson and J. Zubieta, Inorg. Chem., 1982, 21, 4108.

36 A. W. Addison, P. J. Burke, K. Henrick, T. N. Rao and E. Sinn, Inorg. Chem., 1983, 22, 3645 .

37 P. J. M. W. L. Birker, J. Helder, G. Henkel, B. Krebs and J. Reedijk, Inorg. Chem., 1982, 21, 357.

38 F. J. Rietmeijer, P. J. M. W. L. Birker, S. Gorter and J. Reedijk, J. Chem. Soc., Dalton Trans., 1982, 1191

39 M. B. Ferrari, A. B. Corradi, G. G. Fava, C. G. Palmieri, M. Nardelli and C. Pelizzi, Acta Crystallogr., Sect. B. 1973, 29, 1808.

40 K. N. Raymond, D. W. Meek and J. A. Ibers, Inorg. Chem., 1968, 7, 1111.

41 B. J. Hathaway and A. E. Underhill, J. Chem. Soc., 1961, 3094.

42 E. Bernarducci, W. F. Schwinding, J. L. Hughey, K. Krogh-Jespersen and H. J. Schugar, J. Am. Chem. Soc., 1981, 103, 1686.

43 B. J. Hathaway and D. E. Billing, Coord. Chem. Rev., 1970, 5, 143.

44 B. J. Hathaway, 'Comprehensive Coordination Chemistry. The Synthesis, Reactions, Properties \& Applications of Coordination Compounds,' eds. G. Wilkinson, R. D. Gillard and J. A. McCleverty, Pergamon, Oxford, 1987, vol. 5, pp. 53, 533-774.

45 B. N. Figgis and R. S. Nyholm, J. Chem. Soc., 1959, 338; B. J. Hathaway and D. G. Holah, J. Chem. Soc., 1964, 2400.

46 M. di Vaira, C. A. Ghilardi and L. Sacconi, Inorg. Chem., 1976, 15, 1555 .

47 L. Sindellari, B. Zarli, S. Sitran and E. Celon, Inorg. Chim. Acta, 1982, 64, L79.

48 O. Alnagi, M. Zinoune, A. Gleizes, M. Dartiguenave and Y. Dartiguenave, Nouv. J. Chim., 1980, 4, 707.

Received 24th August 1992; Paper 2/04561C 